\title{
Technological Monitoring Study Based on Invention Patents of Omeprazole and Derivatives with Pharmaceutical Applications
}

\author{
Leandra Guimarães de Oliveira, Tatiana Carestiato', Cheila Gonçalves Mothé2, \\ Raimundo Vicente de Souza ${ }^{3}$
}

\begin{abstract}
The current study intends to present the relevance of omeprazole, esomeprazole, rabeprazole, pantoprazole and lansoprazole by means of the technological foresight study, through invention patent documents from Brazilian applicants as indicators of innovation. The European database of patents (Espacenet), Word Patent Index (DERWENT) and the Brazilian Patent Base of INPI were used, combining keywords and International Patent Classifications. The major applicants, countries of publication and claims categories were mapped. The $2 / 2$ patent requests collected are mainly distributed in Chemistry, Pharmacy and Pharmacology areas. The results obtained revealed that the US was the main country with studies directed to this technological area (59 patent applications) and the major applicant was the company Astrazeneca $A B$. Therefore, we can understand that this is a promising technology that may reflect in an increase of R\&D activities and patent applications in this area.
\end{abstract}

Keywords: omeprazole; technological foresight; pharmaceutical patents.

\footnotetext{
' Brazilian Institute of Industrial Property (INPI-Br), Rua Mayrink Veiga, 9 - Centro, 20 Andar, CEP: 20.090-910, Rio de Janeiro, RJ, Brazil, Tel.: +55 (2I) 21393379, E-mail: leandra@inpi.gov.br; tatianac@inpi.gov.br

${ }^{2}$ Department of Chemical Engineering, Federal University of Rio de Janeiro, Bloco E - Sala E-205 - Ilha do Fundão, CEP 2194I-909,

Rio de Janeiro, RJ, Brazil, Tel.: +55 (2I) 2562-7536, E-mail: cheila@eq.ufri.br

${ }^{3}$ Federal University of Lavras (UFLA) - Fundação de Apoio ao Ensino, Pesquisa e Extensão (FAEPE), Lavras, MG, Brazil,

Tel.: + 55 (35) 3829-1729, E-mail: rvsousa@dmv.ufla.br
} 


\section{Introduction}

James M. Utterback and William J. Abernathy (2004) present historical studies of innovations in their organizational environments, technical and economic. Describe how changes occur according to patterns observed in various industries and sectors. It is considered that the model incorporates the realities of the market, enabling an evaluation of several conditions necessary for rapid innovation with high levels of production and productivity.

According to Joseph Schumpeter, innovation is not the same as invention. Innovation can be considered the first commercial use of new product, process, device or system. Kline \& Rosenberg (1986), reports that innovation is any change in the socio-technical manufacturing, distribution or use which allows an improvement in terms of cost, quality or service to consumers and employees, considering the degree of uncertainty to achieve success and the life cycle stage in which the products are found.

Regarding product innovations, Utterback (1994) notes that the so-called "Hard innovation" in the product eventually ends with the consolidation of a dominant design as the market has its expectations for the product in terms of features, format, and specific skills, in other words, product innovations become much smaller, where the focus of Research and Development is on "incremental innovations" of the existing features that will be standardized.

The basic premise for any country to develop technological advance activities is having a sharp scientific and technological qualification. In this context, Brazil has gradually supported the development of scientific activities that allow technological growth in various areas, making new products like pharmaceuticals to be developed, and being of fundamental importance to population.

The pharmaceutical area is a research-intensive industry, which means they are always doing research, and throughout history they have presented a fast innovation rate implemented by companies in relation to other institutions. The release of new or enhanced products represents a key element in the pattern of industry competition, particularly in the pharmaceutical industry, allowing technological innovation, demanding heavy investments in research and development and that also relies on the International Intellectual Property System and massive marketing and advertising costs (Carvalho, D. S. et al. 2009).

Facing the world's demands for new compounds and therapeutic methods that prevent and treat diseases whose treatments are still a challenge to scientists nowadays (like: cancer, AIDS, cardiovascular diseases, among others), together with the high cost of biopolymers to pharmaceutical use; it is necessary to develop new technologies using these biopolymers as pharmaceutics. And, as part of the technological innovation development process, the new technologies must be protected utilizing patent rights.

Tidd et al. (1997) consider that the core competences of firms are not always sufficient for the development of new products. In technological trajectories companies should not remain stagnant in their core competencies or distinctive, overlooking or underestimating the new basic skills for the operation of future technological opportunities, they need to develop links with the outside world.

The use of omeprazole is important in the pharmaceutical industry, it is important to assess how it is implemented and how the development of research and development (R\&D) in the area was. In this context, the patent applications are among the most reliable and comprehensive sources of formal information when R\&D, technology, and innovation are analyzed. Patents can be considered indicators of R\&D in a particular industry and thus are directly related to the process of technological innovation, therefore, the information contained in these documents are essential for evaluating the technological overview in a particular area.

For a better analysis of patent applications, techniques applied in technological forecasting studies, such as monitoring and bibliographic studies are the most suitable, especially by the systematic use and because they have preestablished procedures worldwide, making research comparable with other studies in the area.

Technological foresight is the term applied in studies that try to anticipate and understand the potentialities, evolutions, characteristics, and effects of technological changes, particularly its invention, adoption and usage. Thus, through it, it is possible to try to anticipate the technological and scientific advances and participate in a way to influence in the guidance of technological trajectories guaranteeing competitiveness and the survival 
of research institutions. The main point is to identify the chances for development and the options for present action (Coelho et al, 2003).

The Technological foresight was born in the U.S. in the 50's. However, in the 90's there was an increase in such methodologies in developed and developing countries, once more companies and countries made use of these studies to strengthen its competitive capacity (Coelho et al, 2003).

The methods and techniques used in foreseeing are hard to categorize. One of the categories used is the monitoring \& intelligence systems and the other one is the trend analysis. In a way that these categories emphasize how future conditions evaluations rely on present conditions (Coelho et al, 2003).

Monitoring is the process by which pieces of information about foreseeing are monitored, identifying its sources, collecting, analyzing and structuring this information for its use. Thus, monitoring is crucial to any foresight (Coelho et al, 2003).

Malerba describes that the group of actors involved in sectoral systems is heterogeneous. Actors can be represented by companies, users, suppliers and organizations (2003) and the author concludes (2005) that the sectoral system approach enables the identification of "system error" and the variables that may be subject to guidelines / policies. Von Hippel (1998) shows the importance of the functional relationship between companies and individuals that benefit from the products, processes and innovations in services, bringing together innovators and innovation.

Patent analysis comes from the thought that the increase of interest for new technologies will reflect in the growth of Research and Development activities and this will lead to an increase of patent deposits.. Therefore, it is thought that new technologies can be identified by the analysis of patent applications in some fields. The results are generally presented quantitatively, but their use in the decisionmaking process is based on a qualitative evaluation.

In this context, the present study intends to show the relevance of omeprazole, esomeprazole, rabeprazole, pantoprazole and lansoprazole by means of the technological monitoring study through invention patent documents from Brazilian applications as indicators of innovation. In this way, it intends to analyze the uptrend of the use of this molecule in the pharmaceutical industry, the importance of its patenting, its main application in the pharmaceutical industry as well as the major applicant (s), inventor (s), IPC, claims categories and the country (ies) holding the technology in order to try to anticipate the scientific and technological advances and participate in a way to influence in the guidance of technological trajectories guaranteeing competitiveness and the survival of industries and research institutions.

\section{Method}

The methodology used in the development of this paper, was done in three stages. The first one was the selection of a patent document in the pharmaceutical area that uses omeprazole in the European Patents Database, the Espacenet. The document was obtained using the keywords, "omeprazole or esomeprazole or rabeprazole or pantoprazole or lansoprazole" and the international patent classifications "A6IK3I/4439 or A6IPI/04 or C07D40I/I2". The base ep.espacenet.com, also known as EPODOC, is formed by a collection of more than 60 million patent applications from almost all the countries in the world, existing since 1836 and weekly updated. It also offers an option of patent search by families.

The second stage was the selection of patent documents with the keywords, "omeprazole or esomeprazole or rabeprazole or pantoprazole or lansoprazole" on the topic field and $\mathrm{PN}=\mathrm{BR} *$ in the CDerwent, EDerwent, MDerwent Bases with Timespan=All Years.

The third stage was the indexing and treatment of the collected data at INPI Database. The analyzed documents were evaluated using the keywords: "omeprazole or esomeprazole or rabeprazole or pantoprazole or lansoprazole" on the abstract and title fields.

Through the IPC analysis and appearance of key words of all documents found in the search, it is expected the possibility to observe the diversity of topics in the group of collected patents.

\section{Results}

By means of search on the website http://ep.espacenet.com/advancedSearch?locale=en EP, using the following truncation of keywords (omeprazole or esomeprazole or rabeprazole or pantoprazole or lansoprazole) and IPC (A6IK3I/4439 or A6IPI/04 or C07D40I/I2) it was possible to obtain 1275 documents, all documents were analized in order to recover only 
Brazilian Publication Applications ( $\left.B R^{*}\right)$. The results were summarized in a single sheet for comparison of data. Using keywords in the abstract with the link OR (patoprazole or omeprazole or rabeprazole or esomeprazole or lansoprazole) and the Brazilian Patent Number ( $\mathrm{PN}=\mathrm{BR}^{*}$ ) 160 results were searched in DERWENT Databases: http://apps.isiknowledge.com/DIIDW AdvancedSearch inp
ut.do?product=DIIDW\&SID=4DPOGI2k@leGOFMEj6b\&s earch_mode=AdvancedSearch [Accessed March 30, 2010]. The program provides a comparison of the main depositors (Table I), inventors (Table 2), International Patent Classification (Table 3) and area studied (Table 4) on Derwent Database. The results were summarized in a single sheet for comparison of data.

\begin{tabular}{|r|c|c|c|}
\hline Field: Assignee Name & $\begin{array}{c}\text { Record } \\
\text { Count }\end{array}$ & $\begin{array}{c}\% \text { of } \\
\mathbf{1 6 0}\end{array}$ & Bar Chart \\
\hline ASTRAZENECA AB & 37 & $23.1250 \%$ & \\
ASTRA PUBL AB & 23 & $14.3750 \%$ & \\
ASTRA AB & 22 & $13.7500 \%$ & \\
ALTANA PHARMA AG & 12 & $7.5000 \%$ & \\
NYCOMED GMBH & 11 & $6.8750 \%$ & \\
BYKGULDEN LOMBERG CHEM FAB GMBH & 8 & $5.0000 \%$ & \\
RANBAXY LAB LTD & 8 & $5.0000 \%$ & \\
DIETRICHR & 5 & $3.1250 \%$ & \\
LINDER R & 5 & $3.1250 \%$ & \\
ASTRA AG & 4 & $2.5000 \%$ &
\end{tabular}

Table I. Profile of the 10 largest depositors of patent applications of omeprazole and its derivatives.

\begin{tabular}{|c|c|c|c|}
\hline Field: Imventor & $\begin{array}{l}\text { Record } \\
\text { Count }\end{array}$ & $\begin{array}{l}\% \text { of } \\
160\end{array}$ & Bar Chart \\
\hline DIETRICHR & 7 & $4.3750 \%$ & 国 \\
\hline LINDER R & 6 & $3.7500 \%$ & घ \\
\hline LUNDBERG P J & 5 & $3.1250 \%$ & - \\
\hline $\mathrm{KOHLB}$ & 4 & $2.5000 \%$ & 1 \\
\hline LOEVGREN KI & 4 & $2.5000 \%$ & 1 \\
\hline LOVGREN KI & 4 & $2.5000 \%$ & 1 \\
\hline MEIER C & 4 & $2.5000 \%$ & 1 \\
\hline PETEREIT H & 4 & $2.5000 \%$ & " \\
\hline VON UNGE S & 4 & $2.5000 \%$ & 1 \\
\hline ANDERSEN L & 3 & $1.8750 \%$ & I \\
\hline
\end{tabular}

Table 2. Profile of the 10 largest inventors of patent applications of omeprazole and its derivatives. 


\begin{tabular}{|r|c|c|}
\hline Field: International Patent Classification Code & $\begin{array}{c}\text { Record } \\
\text { Count }\end{array}$ & $\begin{array}{c}\% \text { of } \\
\mathbf{1 6 0}\end{array}$ \\
\hline A61K-031/4439 & 104 & $65.0000 \%$ \\
A61P-001/04 & 92 & $57.5000 \%$ \\
A61K-000/00 & 87 & $54.3750 \%$ \\
A61P-001/00 & 79 & $49.3750 \%$ \\
A61K-031/4427 & 69 & $43.1250 \%$ \\
A61K-031/44 & 63 & $39.3750 \%$ \\
C07D-401/12 & 61 & $38.1250 \%$ \\
A61K-009/20 & 49 & $30.6250 \%$ \\
C07D-401/00 & 46 & $28.7500 \%$ \\
A61K-045/00 & 42 & $26.2500 \%$
\end{tabular}

Table 3. Profile of the main IPC of patent applications of omeprazole and its derivatives.

\begin{tabular}{r|c|c|c|} 
Field: Subject Areas & $\begin{array}{c}\text { Record } \\
\text { Count }\end{array}$ & $\begin{array}{r}\% \text { of } \\
\mathbf{1 6 0}\end{array}$ & Bar Chart \\
\hline CHEMISTRY & 160 & $100.0000 \%$ & \\
\hline PHARMACOLOGY \& PHARMACY & 160 & $100.0000 \%$ & \\
POLYMER SCIENCE & 65 & $40.6250 \%$ & \\
FOOD SCIENCE \& TECHNOLOGY & 13 & $8.1250 \%$ & \\
AGRICULTURE & 12 & $7.5000 \%$ & \\
INSTRUMENTS \& INSTRUMENTATION & 12 & $7.5000 \%$ & \\
GENERAL \& INTERNAL MEDICINE & 11 & $6.8750 \%$ & \\
EIOTGINEERING & 4 & $2.5000 \%$ & \\
\hline
\end{tabular}

Table 4. Profiles of 10 major areas of patent applications of omeprazole and its derivatives.

\begin{tabular}{|c|c|c|}
\hline & Abstract & Title \\
\hline OMEPRAZOL & 27 & 16 \\
\hline RABEPRAZOL & 2 & 1 \\
\hline ESOMEPRAZOL & 4 & 2 \\
\hline LANSOPRAZOL & 4 & 0 \\
\hline PANTOPRAZOL & 10 & 9 \\
\hline TENATOPRAZOL & 5 & 5 \\
\hline
\end{tabular}

Table 5. Number of Patent Applications recovered by INPI Database. 
Another search in the INPI Database using the terms pantoprazole, omeprazole, lansoprazole, rabeprazole, esomeprazole and tenatoprazole on the abstract and title fields: http://pesquisa.inpi.gov.br/MarcaPatente/jsp/servimg/ validamagic.jsp?BasePesquisa=Patentes [Accessed February 13, 2010]. Table 5 presents a summary of the search performed. Thirty-seven (37) patent applications filed in Brazil in the period studied were recovered. The results were summarized in a single sheet for comparison of data.

Finally, all data were gathered and proved to be relevant, making a total of 212 Patent applications.
There were the profile of the depositors (Figure I), the main inventor (Figure 2), the leading International Patent Classification (Figure 3), the main applicant country (Figure 4), category of claims (Figure 5) and terms found in the search performed (Figure 6). Figure I shows that the principal applicant was the company Astrazeneca $A B$, with 46 invention patent applications. The second largest depositor was Pfizer Inc., containing eight patents applications. After, the third largest applicant was the company Altana Pharma AG with 6 patent applications from 1992 to March 2010.

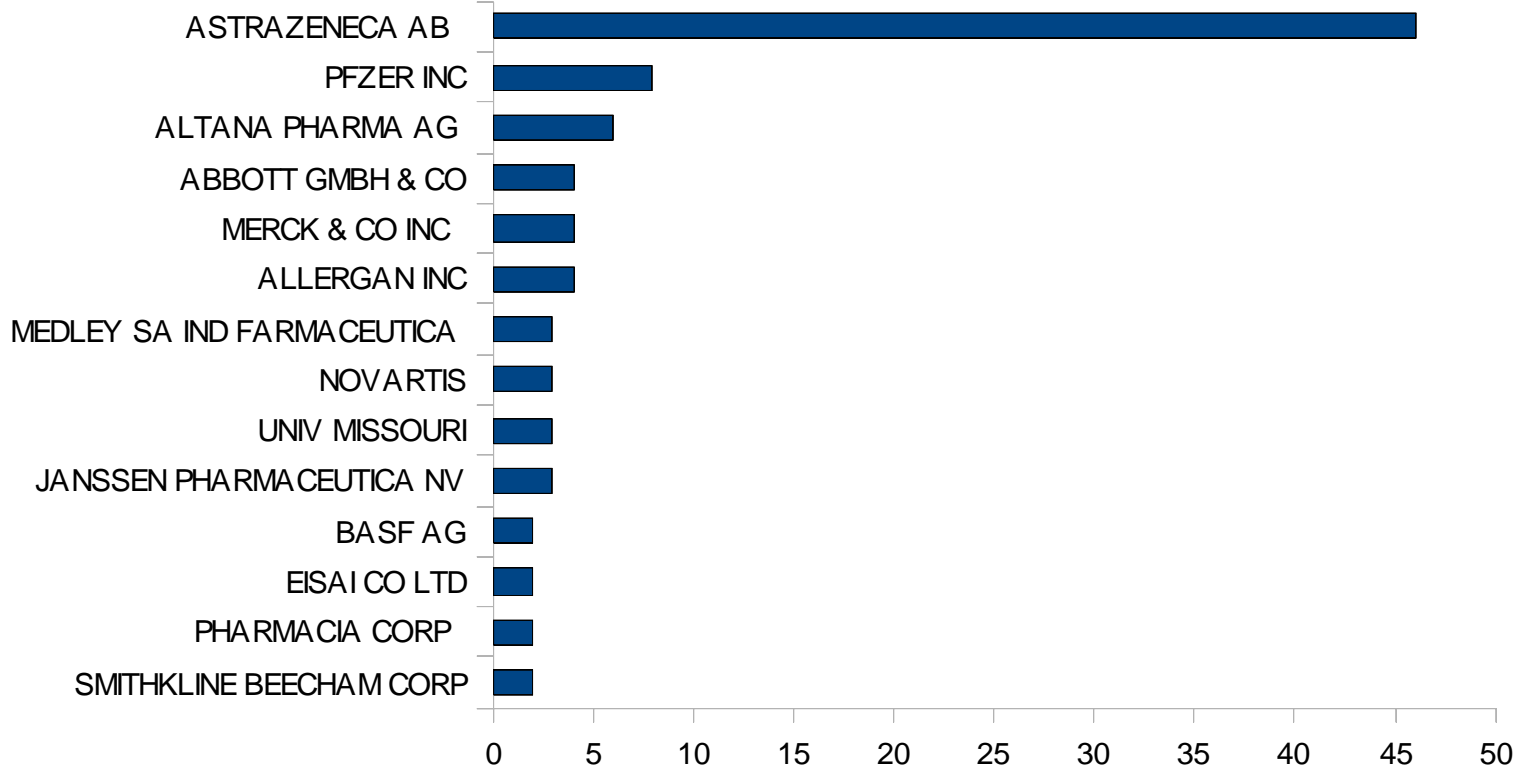

Figure I. Main depositors by number of patent applications. 


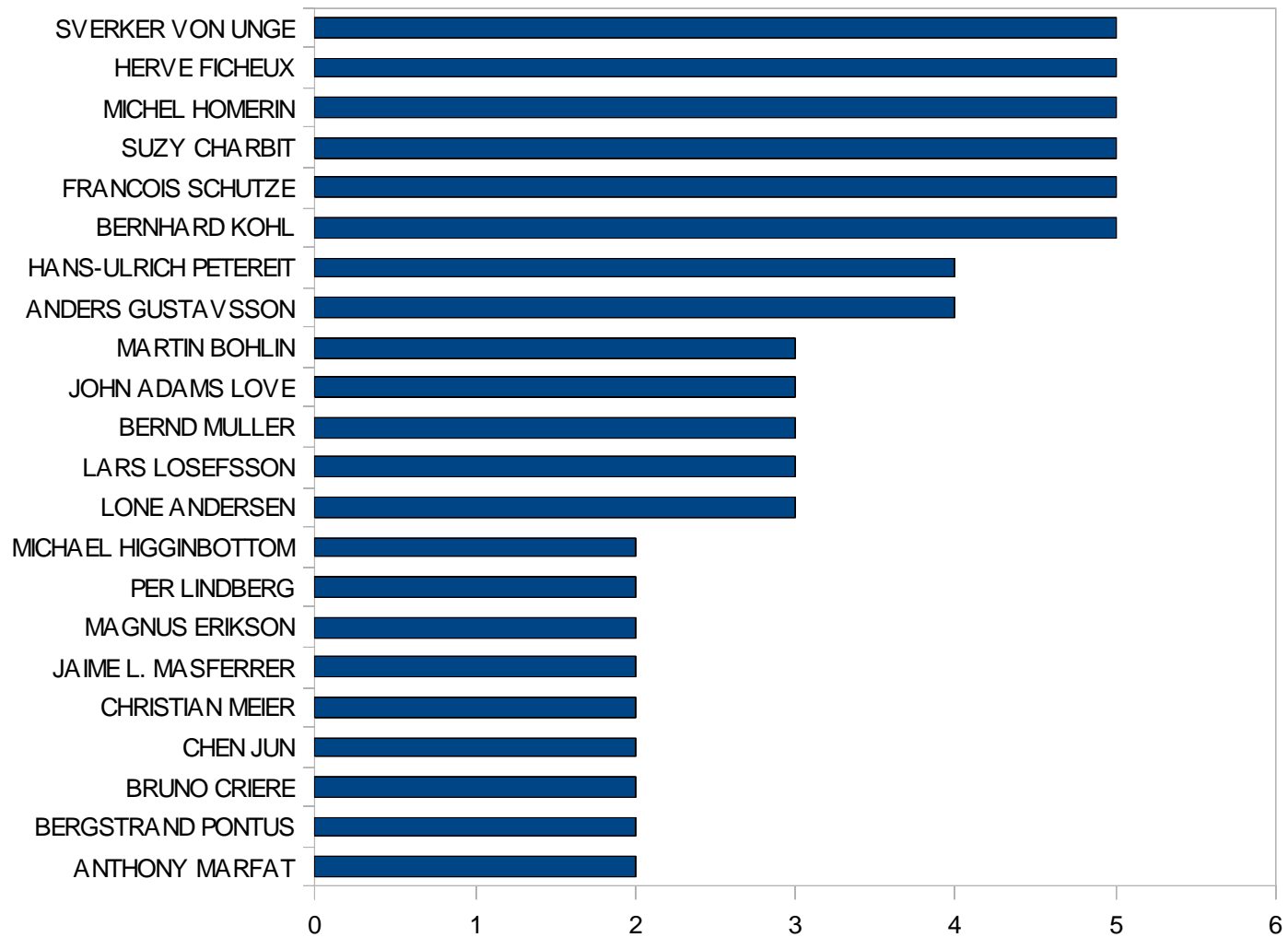

Figure 2. Graph of major inventors by number of patent applications.

The results presented in Figure 2 show the heterogeneity of the inventors, with a low incidence of a specific name. The inventors were mainly BERNHARD KOHL, FRANCOIS SCHUTZ, SUZY CHARBIT, MICHEL HOMERIN, HERVE FICHEUX AND SVERKER VON UNGEI with five deposits of patent applications for each inventor.

According to the information below, it seems that the use of the IPC as a source of information is extremely necessary when evaluating this technological area, since it may have different applications for omeprazole in different areas. From Figure 3 below different classifications were taken, where the main ones were C07D 40I/I2 and A6IK 3 I/4439 and A6IP I/04 which appears 50, 48 and 43 times respectively in the analyzed patent documents, as it can be observed in picture 5 . It is valid to stress that this analysis considers all the subgroups appearing in the analyzed patent documents once each patent can have more than one international classification to refer to all protection categories claimed.

This result matches each International Patent Classification definition that follows:

C07D 40I/12 - Heterocyclic compounds containing two or more hetero rings, having nitrogen atoms as the only hetero atoms ring, at least one ring being a six-membered ring with only one nitrogen atom linked by a carbon chain containing aromatic rings.

A6IK 3I/4439 - Medicinal preparations containing organic-active ingredients, containing further heterocyclic ring systems, containing a five-membered ring with nitrogen as a hetero atom ring, e.g. omeprazole.

A6IP I/04 - Drugs for disorders of the alimentary tract or the digestive system, for ulcers, gastritis or reflux esophagitis, e.g. antacids, inhibitors of acid secretion, mucosal protectants. 


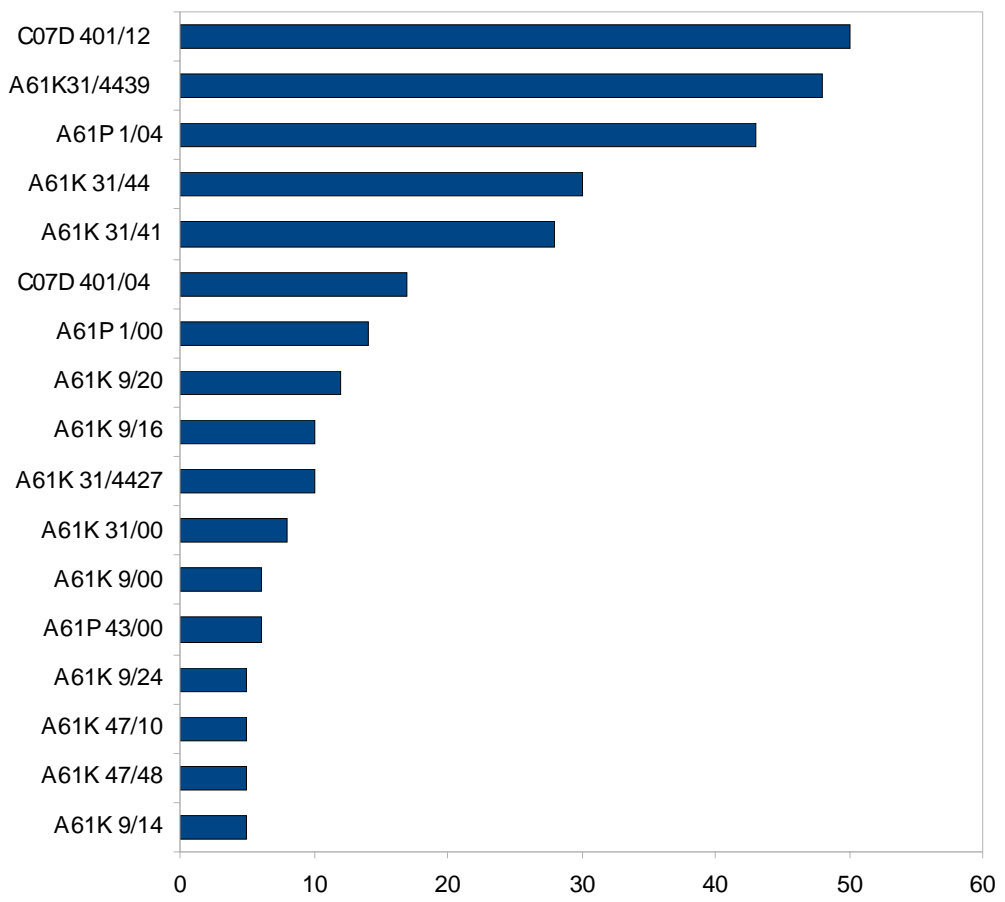

Figure 3. Main international patent classifications by number of patent applications

As seen in Figure 4, the country that was the main depositor of patents related to omeprazole and its derivatives was the U.S. with 59 patent applications, followed by four other countries: Sweden, with 45 applications, Germany, with 22 applications, India and
France with 22 and 16 respectively. Only six were identified as patent applications from Brazil, indicating that only $2.8 \%$ of the deposits are of Brazilian residents and 97.2\% are foreign (multinational corporations) that have deposited via international filing (PCT).

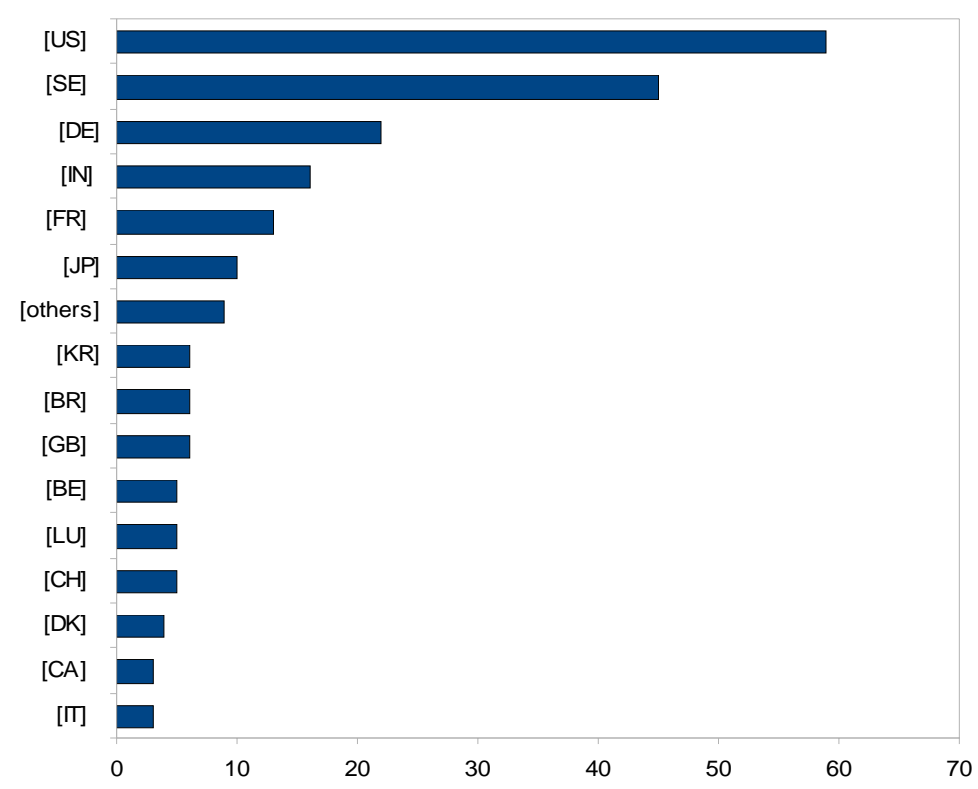

Figure 4. Graph of country distribution by patent application. 
Figure 5 below shows that the most frequent type of claim was composition (125 results), then process (86 results) and compound (77 results). In the category of claims, there were found 46 patents of methods and only three results for combination. It is worth stressing that the same schedule of claims may contain more than one different category of claim, each category is called "independent claim" that may be linked to the main claim or not.

The most present term in the patent applications analyzed was omeprazole with 68 occurrences, followed by pantoprazole (18 data), lansoprazole (15 data), esomeprazole (14 data) and Rabeprazol (I0 data) as shown in Figure 6.

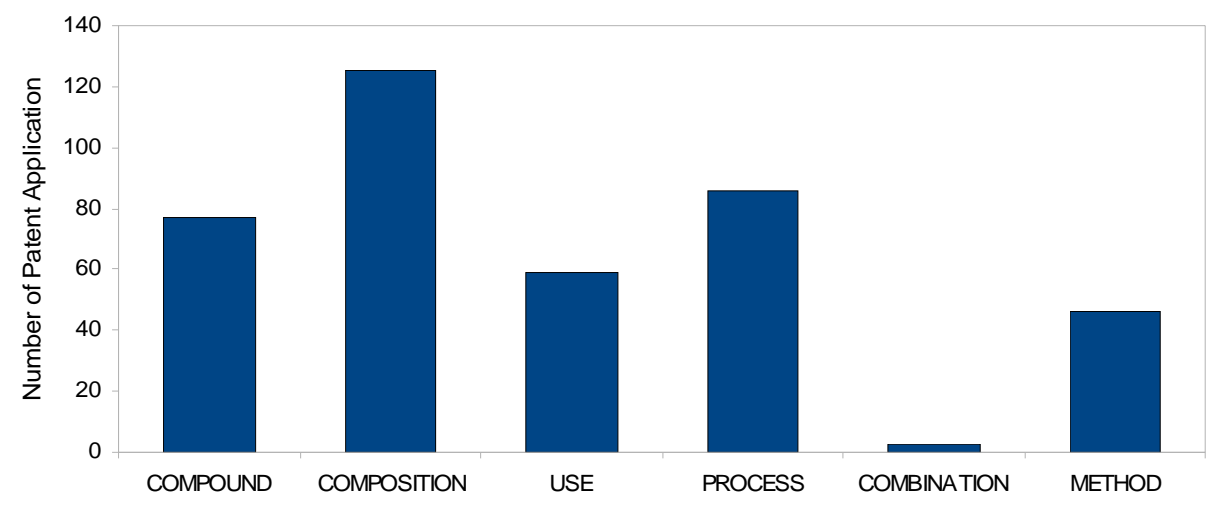

Figure 5. Number of patent applications and category claims.

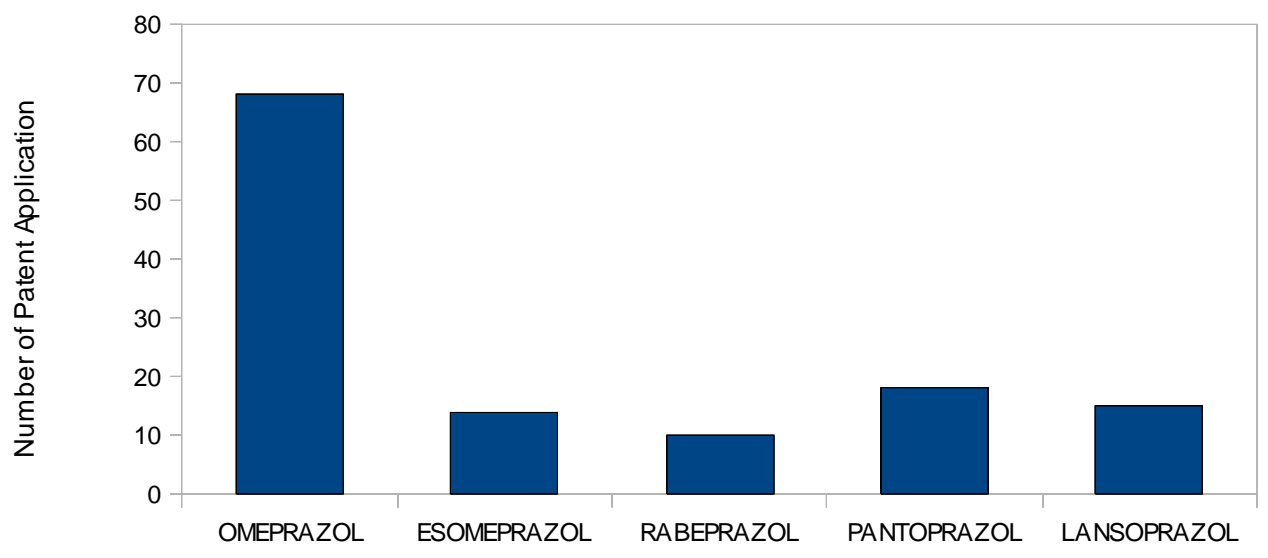

Figure 6. Kind of omeprazole and derivatives

\section{Discussion}

Among the main depositors of patent applications on Omeprazole and its derivatives in Brazil, there were identified companies, universities and research institutes that strive in various categories of claims: $59 \%$ in pharmaceutical composition, $41 \%$ in manufacturing process, $36 \%$ in compost, $28 \%$ in use, $22 \%$ in method and $1 \%$ in drug combinations.
Analyzing the countries of the depositors of patent applications of its derivatives Omeprazole, published between 1992 and March 2010, it was noticed that these are mainly from the USA (59 applications), followed by Sweden (45 applications) and Germany (22 applications). Brazil does not present a significant number of patent applications in that theme (6 applications). 
The period from 1992 to March 2010 showed that there is a concentration of patent applications in a few institutions of American, Swiss, or German origin, and the three main depositors are responsible for $28 \%$ of all patent applications in the area. This shows that the search for patent protection in Brazil is being conducted mainly by large multinational chemical companies that use omeprazole and its derivatives in pharmaceuticals. The main depositors are Astrazeneca $A B$, Pfizer Inc. and Altana Pharma AG, with 46, 8 and 6 patent applications respectively.

It is important the combination of terms related to omeprazole, such as "omeprazole", "pantoprazole", "lansoprazole", "rabeprazole" or "esomeprazole" as well as the use of the International Patent Classification - IPC in search of information needed to monitor the subject.

\section{References}

ABERNATHY, W. J., Utterback, J. M. (2004). Patterns of industrial innovation. In: Burgelman et al. (2004). Strategic Management of Technology and Innovation, Mc. Granwhill, p. 202-208.

BARBOSA, D.B. (2003). Uma introdução à propriedade intelectual, $2^{\mathrm{a}}$ edição, Lumen Juris editora, Rio de Janeiro, 1268p.

BOLDRIN, M., Levine, D.K. (2008). Perfectly competitive innovation. Journal of Monetary Economics, 55, 435-453

CARVALHO, D.S., Oliveira, L. G., Winter, E., Mothé, C. G. (2009). Technological Foresight Based on Citing ad Cited Patents of Cellulose with Pharmaceutical Applications. Journal of Technology Management \& Innovation, 4, 32-4I.

CHAVES, G.C., Oliveira, M.A., Hasenclever, L., Melo, L.M. (2007). A evolução do sistema internacional de propriedade intelectual: proteção patentária para o setor farmacêutico e acesso a medicamentos. Cadernos de Saúde Pública, 23, 257-267

CHRISTENSEN, Grossman, Hwang (2009). The role of disruptive technology and business model innovation in making products and services affordable and accessible (Cap. I.) and The technological enablers of disruption (Cap. 2), In: The innovator's prescription, p. I-72
COELHO, G. M.. Coelho D. M. S. (2003). Metodologias e Experiências Nacionais e Internacionais, Nota Técnica 14, In: Projeto CTPETRO Tendências Tecnológicas, Instituto Nacional de Tecnologia, Rio de Janeiro, Brasil. http://www.davi.ws/prospeccao_tecnologica.pdf [Accessed March 17, 2010]

FLORÊNCIO, A. P. S., Melo, J. H. L., Mota, C. R. F. C., Melo-júnior, M. R., Hippel, Von, Eric. (1998). Overview (cap. I), Users as innovators (cap. 2), Variations in the functional source of innovation (cap. 3) In: The sources of innovation, p.3-42

KLINE, S.J., Rosenberg, N. (1986). An overview of innovation, p. 275-305

LEONARD-BARTON (1995). A natureza das aptidões e das limitações, cap. I (Aptidões estratégicas) e cap. 6 (Importação e absorção de saber tecnológico de fora da empresa), p. 19-46, 163-206

MALERBA, F. (2003). Sectoral systems and innovation and technology policy. Revista Brasileira de Inovação, 2(2), julho/dezembro, 329-375

MALERBA, F. (2005). Sectoral systems of innovation, Cap. 14, p. 380-406

MOREIRA, A.C., Müller, A.C.A., Pereira Jr., N., Antunes, A.M.S. (2006) Pharmaceutical patents on plant derived materials in Brazil: Policy, law and statistics. World Patent Information, 28, p. 34-42

TIDD, J., BESSANT J., PAVITT K. (1997). Paths: exploiting technological trajectories, (cap. 5). In: Managing Innovation, Wiley, New York, p. 105-132

UTTERBACK, J. M. (1994). Innovation and Industrial Evolution Mastering the Dynamics of Innovation, cap. 4, 5 and 6, In: Harvard Business School Press, Boston, p. 85-I58

WEST, J., GALLAGNER, S. (2006). Challenges of open innovation: the paradox of firm investment in open-source software. R\&D Management, 3|9-33। 